\title{
Peningkatan Kualitas Guru dengan Pelatihan Google Classroom sebagai Media Alternatif School From Home pada SMK Puspita Persada Jakarta Selatan
}

\author{
Ahmad Pudoli $^{1}$, Mardi Hardjianto ${ }^{2}$, Devit Setiono ${ }^{3}$ \\ 1,2,3 Fakultas Teknologi Informasi, Universitas Budi Luhur \\ Jl. Ciledug Raya, Petukangan Utara, Pesanggrahan, Jakarta Selatan \\ e-mail: ${ }^{1}$ ahmad.pudoli@budiluhur.ac.id, ${ }^{2}$ mardi.hardjianto@budiluhur.ac.id, \\ 3devit.setiono@budiluhur.ac.id
}

\begin{abstract}
Abstrak
Adanya pandemi COVID-19 di awal tahun 2020 ini menyebabkan perubahan besar dalam kegiatan masyarakat saat ini. Mulai dari kegiatan perdagangan, ekonomi, pekerjaan serta dalam dunia pendidikan. Sekolah wajib turut serta dalam pencegahan penyebaran virus COVID-19 ini dengan mengubah pola ajar sesuai dengan intruksi Kementrian Pendidikan dan Kebudayaan Republik Indonesia, dimana kegiatan belajar mengajar dilakukan dari rumah. Sekolah Menengah Kejuruan Puspita Persada turut serta dalam menyukseskan program pemerintah dengan mengubah pola ajar dari rumah. Namun karena intruksi ini diberikan secara cepat, SMK Puspita persada belum menyiapakan dengan matang teknis dalam belajar mengajarnya. Saat ini metode mengajar dilakukan dengan menggunakan WhatsApp Group dan email. Tentunya dengan metode ini masih perlu dikembangkan agar penyampaian materi ajar lebih sempurna lagi. Tujuan dari kegiatan ini adalah dengan memberikan pelatihan menggunakan fasilitas dari Google yaitu Google ClassRoom guna meningkatkan kemampuan dari guru dalam memberikan dan menyampaikan materi secara maksimal dan berbasis teknologi yang lebih baik. Metode yang akan dilakukan dalam kegiatan ini adalah pelatihan dengan tatap muka (jika memungkinkan) namun tetap menerapakan physical distancing dalam penyampain materinya. Metode ini akan disesuaikan pada waktu pelaksanaan menyesuaikan dengan kondisi yang ada. Berdasarkan kegiatan Abdimas, dapat disimpulkan bahwa pelatihan google classroom memberikan manfaat yang uar biasa untuk para guru. Guru sangat antusias dan tertarik dengan penggunaan google classroom, guru mengetahui aplikasi yang bisa digunakan sebagai media pembelajaran, guru dapat lebih mudah untuk mengelola kelas, lebih hemat waktu, dan memberikan contoh kepada siswa untuk menjaga lingkungan dengan mengurangi penggunaan kertas.
\end{abstract}

Kata Kunci: google classroom; covid-19;sekolah

\begin{abstract}
The COVID-19 pandemic in early 2020 is causing major changes in community activities today. Starting from trade, economy, jobs as well as in the world of education. Schools must participate in preventing the spread of the COVID-19 virus by changing teaching patterns in accordance with the instructions of the Ministry of Education and Culture of the Republic of Indonesia, where teaching and learning activities are carried out from home. Puspita Persada Vocational High School participated in the success of the government program by changing the teaching pattern from home. However, because this instruction was given quickly, SMK
\end{abstract}

This work is licensed under a Creative Commons Attribution-ShareAlike 4.0 International License.

Published by LPPM Universitas Bina Sarana Informatika 
Puspita persada has not prepared technically thoroughly in teaching and learning. Currently the teaching method is done using WhatsApp Group and email. Of course, this method still needs to be developed so that the delivery of teaching materials is more perfect. The purpose of this activity is to provide training using Google's facility, Google ClassRoom, to improve the ability of teachers to deliver and deliver materials to the maximum and based on better technology. The method that will be done in this activity is face-to-face training (if possible) but still apply physical distancing in the presentation of the material. This method will be adjusted at the time of implementation in accordance with existing conditions. Based on Abdimas activities, it can be concluded that google classroom training provides tremendous benefits for teachers. Teachers are very enthusiastic and interested in using google classroom, teachers know applications that can be used as a learning medium, teachers can be easier to manage classes, save time, and give examples to students to maintain the environment by reducing paper use.

Keywords: google classroom; covid-19;school

\section{Pendahuluan}

Pembatasan Sosial Berskala Besar (PSBB) pada masa pandemik seperti ini menjadi salah satu upaya pemerintah dalam mengurangi penularan virus covid-19, termasuk dalam linkungan sekolah. Guru dan siswa dituntut untuk melakukan perubahan pola dalam belajar mengajar dengan pembelajaran jarak jauh dengan media digital. Belajar adalah kegiatan atau aktivitas individu dalam proses mengetahui dan memahami sesuatu (Priantini, 2016). Manusia dalam menjalani kehidupannya secara tidak langsung merupakan proses belajar yang berkelanjutan. Dan selanjutnya pendidikan dilakukan dalam lembaga formal seperti sekolah. Materi yang dipelajari juga meliputi semua disiplin ilmu termasuk dalam hal kemandirian pribadi, ilmu sains, ilmu sosial, maupun ilmu agama (Imaduddin \& Nur Utomo, 2012). Sedangkan mengajar merupakan proses alamiah dalam kehidupan. Setiap manusia pasti melakukan proses pengajaran kepada manusia lainnya (Wana et al., 2017) Media pembelajaran sendiri juga memiliki peran yang sangat singnifikan dalam menentukan kelancaran proses perkuliahan (Kurnia \& Nugroho, 2017;Asyhar, 2012). Media pembelajaran dapat berupa teknologi, salah satunya memanfaatkan internet. Penerapan media pembelajaran sangat membantu keberhasilan dalam proses belajar mengajar (Muslih, 2016). Proses pembelajaran melalui media internet sudah sering dilakukan diberbagai institusi. Hal ini bertujuan untuk meningkatkan kemandirian belajar mahasiswa melalui media pembelajaran seperti virtual class (Sohibun \& Ade, 2017) SMK Puspita Persada adalah sekolah swasta yang berada di wilayah Jakarta Selatan. SMK Puspita Persada tentunya memiliki kewajiban dalam mengikuti instruksi Menteri Pendidikan dan Kebudayaan Republik Indonesia dalam mencegah penyebaran virus ini. SMK Puspita Persada pun, mulai mengubah pola pembelajaran secara digital secara bertahap. Walaupun pada pelaksanaannya memiliki banyak kendala. Mulai dari menentukan media apa yang sesuai dengan karakteristik guru dan siswa. Sampai dengan mempertimbangkan bagaimana materi yang disampaikan dapat dilakukan secara maksimal.

Kegiatan yang dilakukan saat ini oleh SMK Puspita persada dalam melakukan pola pembelajaran school form home adalah dengan membentuk Whatsapp Group dengan siswanya serta mewajibkan setiap siswa memiliki email yang dapat digunakan dalam menyerahkan tugas dan juga materi yang akan diberikan guru. Pada pelatihan ini diterapkan pembelajaran jarak jauh dengan menggunakan koneksi internet (daring) yang memanfaatkan salah satu aplikasi google kelas (classroom.google.com) dengan pendekatan model pembelajaran kolaboratif. Dengan menggunakan aplikasi ini guru dapat memeberikan materi secara daring sehingga siswa 
dapat mendapatkan materi dengan lebih mudah. Proses pemberian tugas dan kuis dapat juga dilakukan secara online akan mempermudah proses belajar mengajar. Siswa dapat memberikan pertanyaan langsung melalui komentar pada materi yang belum dipahami. Siswa lain juga dapat saling berinteraksi satu dengan lainnya, sehingga diskusi kelas bisa berjalan dengan baik.

\section{Metode}

Metode kegiatan pelatihan ini dilakukan berdasarkan pendekatan prosespembelajaran teori dan pembelajaran praktek. Perbandingan antara pembelajaranteori dengan pembelajaran praktek berkisar dengan perbandingan sekitar 1 : 2.Metode pelatihan untuk menyampaikan teori, meliputi : ceramah, tanya jawabdan diskusi, sedangkan praktikum terdiri dari metode tanya jawab serta tugasatau latihan. Berikut ini adalah uraian kegiatan pengabdian pada masyarakat yang kami laksanakan di SMK Puspita Persada.

1. Observasi

Kegiatan ini dilakukan dengan mendatangi mitra yaitu Kepala Sekolah Menengah Kejuruan Puspita Persada Jakarta Selatan untuk mengetahui kebutuhan mitra dalam proses pengabdian kepada masyarakat yang akan dilakukan oleh dosen Universitas Budi Luhur. Setelah mengetahui kebutuhan mitra PKM maka dosen membentuk tim PKM sebagai hasil dari survei lokasi mitra (observasi).

2. Wawancara

Wawancara langsung dilakukan kepada Kepala Sekolah Menengah Kejuruan Puspita Persada Jakarta Selatan tentang kebutuhan yang dapat dijadikan sebagai objek pengabdian pada masyarakat.

3. Studi Kepustakaan

Mempelajari teori yang berkaitan dengan tema pengabdian kepada masyarakat, dokumentasi mitra dan mencari informasi dari internet tentang kondisi terbaru dari lokasi mitra.

Dari ketiga metode pengumpulan data di atas maka kami merangkai keterkaitan antara kegiatan yang kami lakukan antara tim dengan pengguna adalah sebagai berikut:

1. Tim melakukan analisis kebutuhan pengguna ke SMK Puspita Persada Jakarta Selatan

2. Tim Dosen membuat hasil analisis kebutuhan dengan merancang kebutuhan pelatihan.

3. Dosen membuat modul pelatihan yang akan digunakan sebagai panduan bagi peserta pelatihan.

4. Dosen melakukan persiapan untuk pelaksanaan pelatihan.

5. Dosen melaksanakan pelatihan dan melakukan evaluasi kepada peserta pelatihan dengan memberikan latihan

\section{Hasil dan Pembahasan}

Kegiatan ini diawali dengan berkunjungnya tim PKM ke tempat mitra yaituSMK Puspita Persada, Petukangan Utara, Jakarta Selatan. Tim bertemu dengankepala sekolah kemudian dilakukan pembuatan syarat admistratif guna pembuatan proposal pengabdian masyrakat. Tim pelaksana melakukan wawancara mengenai penggunaan google classrom di masa pandemi. Dilanjutkan dengan menyiapkanmateri presentasi dan penggandaan hand out. Tim pelaksana menuju tempat mitra dan menyiapkan kebutuhan presentasi dan dokumentasi seperti persiapan paparan dengan LCD Proyektor dan persiapan banner. 


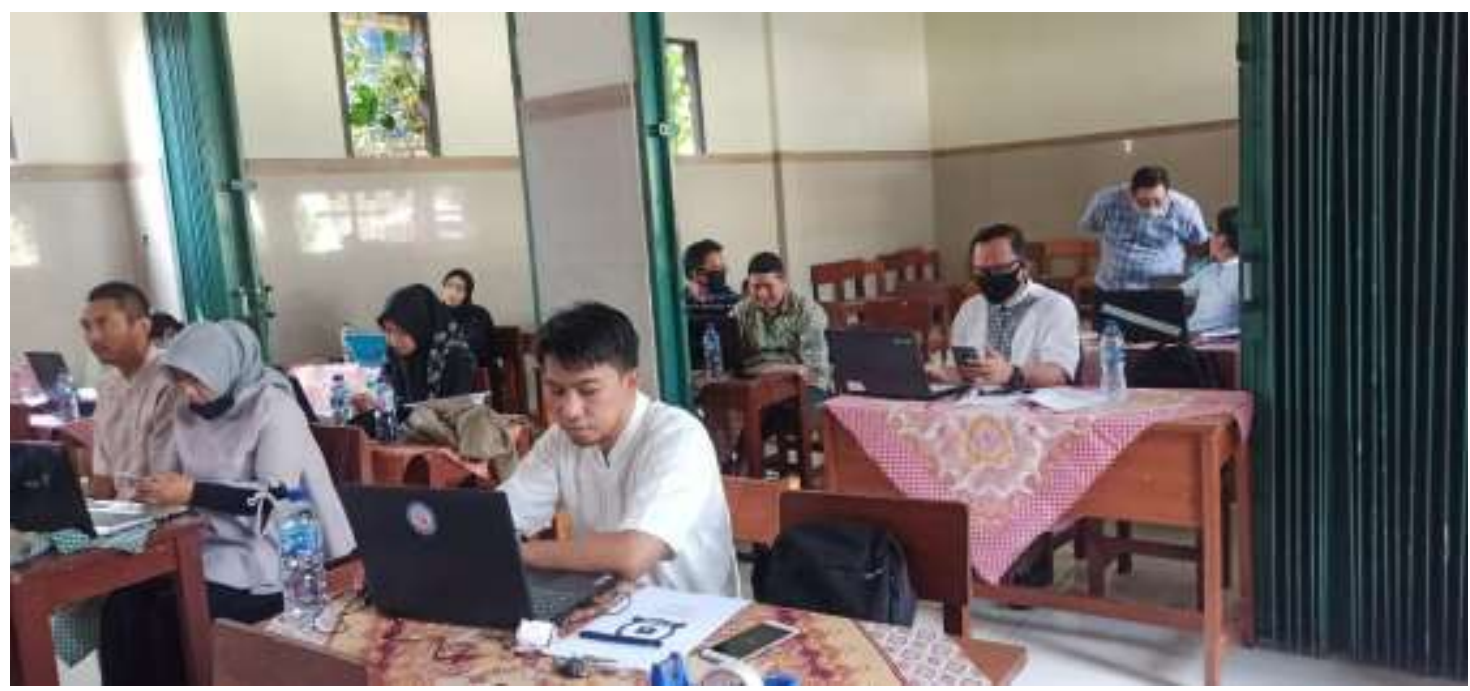

Gambar 1. Suasana Pelatihan PKM

Tim pelaksana mulai memaparkan tentang materi yang disajikan, diawali dengan sebuah pertanya mengenai perubahan dari pembelajaran offline ke online. Didapatkan beberapa kendala terhadap perubahan ini, mulai dari kepahaman tentang google classroom, komunikasi, distribusi tugas dan kendala teknis lainya.

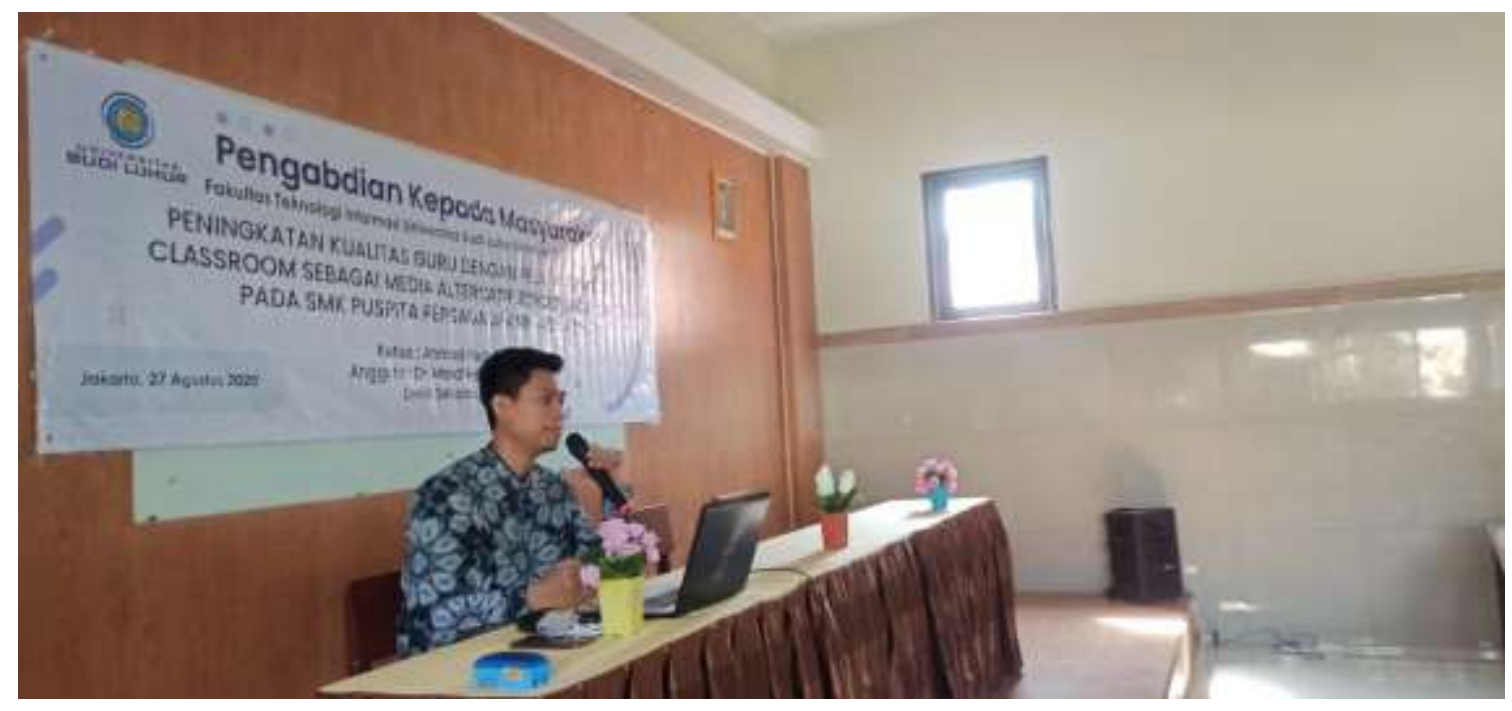

Gambar 2. Salah Satu Tim PKM Memberikan Materi Pelatihan

Hal ini dikarenakan, perubahan yang begitu mendadak tanpa sebuah persiapan yang matang di tengah pandemi seperti ini. Awalnya guru-guru di sekolah ini masih menggunakan whatsaap sebagai media pembelajaran, mengirim tugas dan menilai hasil belajar siswa melalui pesan whatsaapp. Hal ini memiliki kendalah dalam melakukan penilaian, guru harus mendowload dan membaca hasil kerja siswa satu persatu. Hal ini membutuhkan waktu yang lama dan mendaptkan kendala jika tulisan anak didik sulit dibaca. Setelah mendaptkan beberapa bahan diskusi, tim platihan memulai untuk menjelaskan apa itu google class room dan memulai mengoperasikan pembuatan class room.

Pelatihan dimulai dengan memaparkan satu persatu dan langkah-langkah dalam pembuatan kelas melalui google clas room. Selain memaparkan melalui LCD, salah satu tim juga 


\section{ABDITEKNIKA}

Jurnal Pengabdian Kepada Masyarakat

membagikan hand out untuk bisa digunakan sebagai panduan nantinya dan tim lainya mendampingi beberapa peserta yang merasa kesulitan.

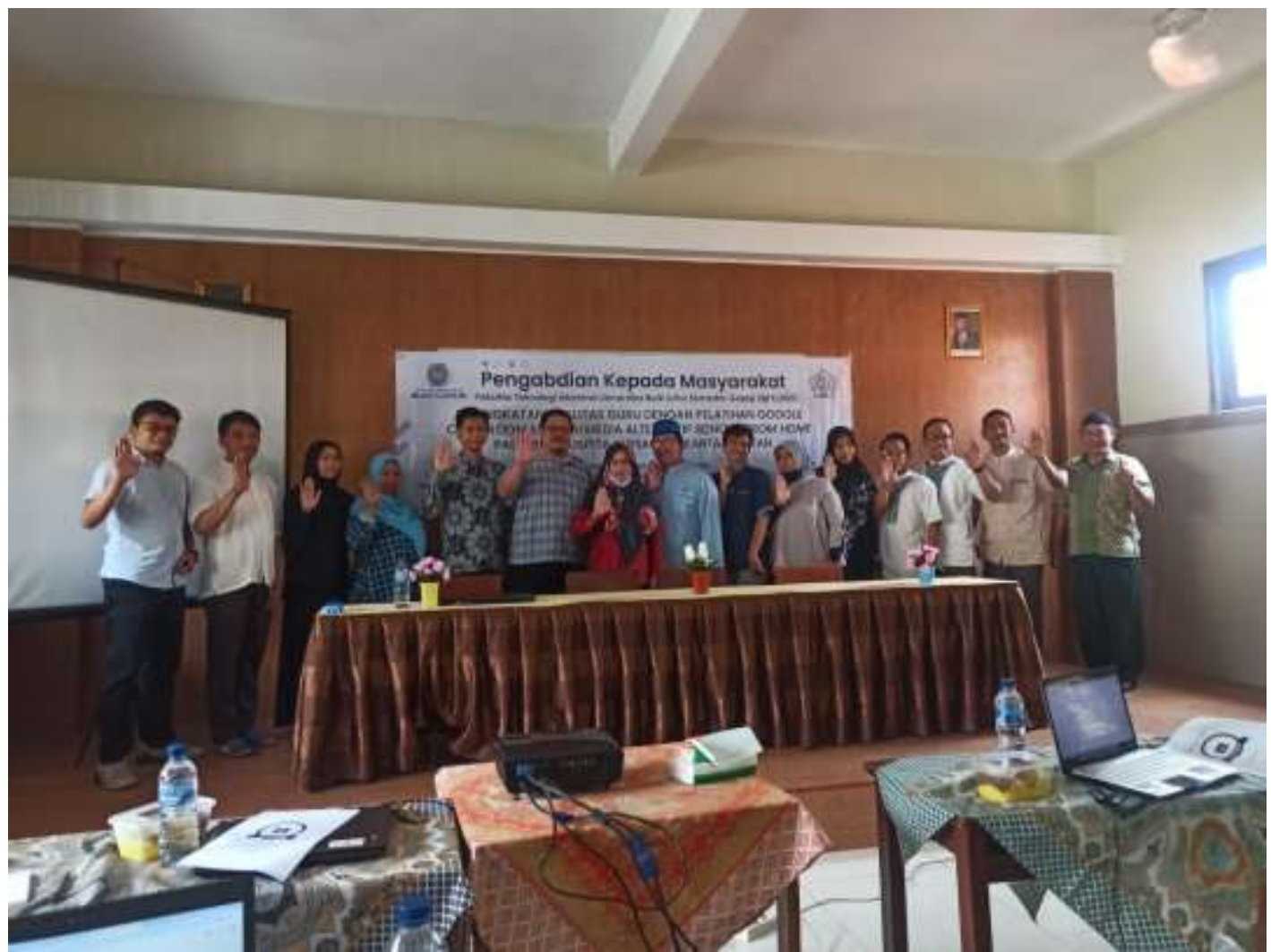

Gambar 3. Sesi Foto Bersama dengan Peserta Pelatihan

Berikut ini adalah hasil dari program pengabdian kepada masyarakat yang dilakukan oleh Tim penulis berdasarkan kuisioner pada saat kegiatan berlangsung:

Tabel 1. Hasil Olahan Kuisioner Kegiatan PKM

\begin{tabular}{|c|c|c|c|c|}
\hline No & Pertanyaan & Hasi & & Keterangan \\
\hline 1 & $\begin{array}{l}\text { Materi yang diberikan tepat atau sesuai dengan kebutuhan. } \\
\text { Pertanyaan pada kuisioner ini adalah : materi yang } \\
\text { diberikan sudah sesuai dengan kebutuhan mitra? }\end{array}$ & $\begin{array}{l}94 \% \text { menjawab } \\
\text { baik sekali }\end{array}$ & $\begin{array}{l}6 \% \\
\text { menjawab } \\
\text { baik }\end{array}$ & Diterima \\
\hline 2 & $\begin{array}{l}\text { Cara penyampaian materi dari intrukstur ke peserta } \\
\text { Dalam pertanyaan di kuisioner ini apakah cara } \\
\text { penyampaian materi dari intrukstur ke peserta? }\end{array}$ & $85 \%$ baik sekali & $15 \%$ baik & Diterima \\
\hline 3 & $\begin{array}{l}\text { Waktu atau durasi pelaksanaan kegiatan } \\
\text { Dalam pertanyaan di kuisioner ini waktu atau durasi } \\
\text { pelaksanaan kegiatan? }\end{array}$ & $\begin{array}{l}80 \% \text { menjawab } \\
\text { cukup }\end{array}$ & $\begin{array}{l}20 \% \\
\text { menjawab } \\
\text { baik }\end{array}$ & Diterima \\
\hline 4 & $\begin{array}{l}\text { Apakah anda mengetahui cara mengoperasikan google } \\
\text { class room setelah mengikuti kegiatan ini? } \\
\text { Dalam pertanyaan di kuisioner ini peserta mengetahui cara } \\
\text { pengoperasian google class room setelah mengikuti } \\
\text { kegiatan ini? }\end{array}$ & $80 \%$ mejawab ya & $\begin{array}{l}20 \% \\
\text { menjawab } \\
\text { mungkin }\end{array}$ & Diterima \\
\hline
\end{tabular}




\section{Kesimpulan}

Berdasarkan pembahasan, dapat disimpulkan bahwa pelatihan google classroom kepada para guru di sekolah Menengah Kejuruan Persada memberikan manfaat yang uar biasa untuk para guru. Guru sangat antusias dan tertarik dengan penggunaan google classroom, guru mengetahui aplikasi yang bisa digunakan sebagai media pembelajaran, guru dapat lebih mudah untuk mengelola kelas, lebih hemat waktu, dan memberikan contoh kepada siswa untuk menjaga lingkungan dengan mengurangi penggunaan kertas.

\section{Daftar Pustaka}

Imaduddin, M. Ch., \& Nur Utomo, U. H. (2012). Efektifitas metode Mind Mapping Untuk Meningkatkan Prestasi Belajar Fisika pada Siswa Kelas VIII, IX(No. 1)

Kurnia, E. D., \& Nugroho, Y. E. (2017). Pelatihan pembuatan media pembelajaran aksara jawa bagi guru bahasa jawa sma di kabupaten Rembang. Jurnal Pengabdian Pada Masyarakat, 2(2), 101-112. doi: 10.30653/002.201722.22.

Muslih. (2016). Pemanfaatan media pembelajaran berbasis ICT pada lembaga pendidikan nonformal TPQ. Dimas: Jurnal Pemikiran Agama untuk Pemberdayaan, 16(2), 215-234. doi: 10.21580/dms.2016.162.1090.

Priantini, D. A. M. M. (2016). Pengaruh Metode Mind Mapping Terhadap Keterampilan Berfikir Kreatif dan Prestasi Belajar IPS. Jurnal Kajian Pendidikan Widya Accarya, (20850018), 118-131.

Sohibun, S., \& Ade, F. Y. (2017). Pengembangan media pembelajaran berbasis virtual class berbantuan Google Drive. Tadris: Jurnal Keguruan dan Ilmu Tarbiyah, 2(2), 121-129. doi: 10.24042/tadris.v2i2.2177.

Wana, P. R., Pangestu, W. T., \& Agustina, D. A. (2017). Menggunakan Metode Pembelajaran Mind Mapping dan Direct Instruction Pada Siswa Kelas V SDN Jiwan 01 Madiun. Jurna Pendidikan Ke-SD-An, 3, 83-87 